\title{
Beliefs and Sexual Education Influence the Development of Female Sexual Dysfunctions? - A Literature Review
}

\author{
LORENA CALLINE BRITO ROCHA, MARGARANY MASCARENHAS \\ MENDES and ALINE MOREIRA RIBEIRO*
}

Minas Gerais Center for Higher Education, Campo Belo, Minas Gerais, Brazil.

\begin{abstract}
Background: Understanding women in their entirety, considering not only organic aspects but also psychological, sentimental, relational, and beliefs aspects is of paramount importance for the individualized approach to sexual dysfunction. The professional should seek to understand the factors that lead to the development of dysfunctions. Thus, understanding whether sexuality beliefs and education influence sexual dysfunctions may be a differential to treatment success, as well as in the management of attention directed toward women with dysfunction.

Aim: To identify the influence of beliefs and sexual education for the development of female sexual dysfunctions.

Methods: We searched publications in the databases SciELO, PubMed and Virtual Health Library covering the following key words: "female sexual dysfunctions", "beliefs" and "sexual education". A descriptive analysis of the results was performed in which data presentation followed exclusively the terminologies followed by the authors.

Results: Five hundred and fifty-two articles were found. Considering the exclusion criteria, only two articles were selected for review. The sample size was 337 women with a age range of 28.7 to 35 years. The studies were conducted in Portugal and Iran. According to the authors, sexual health education is effective in improving female sexual function, since the belief that sexual desire and pleasure are sinful seems to be related to hypoactive sexual desire. Beliefs about body image may be related to orgasmic disorders in women.

Conclusion: The shortage of studies addressing the influence of education and beliefs on female sexual dysfunction demonstrates the importance and necessity of new research using specific markers in order to contribute to a broader and more effective discussion.
\end{abstract}

CONTACT Aline Moreira Ribeiro $\$ alinemrib@gmail.com. 9 Minas Gerais Center for Higher Education, Campo Belo, Minas Gerais, Brazil.

\section{(c) (i)}

(c) 2019 The Author(s). Published by Enviro Research Publishers.

This is an Open Access article licensed under a Creative Commons license: Attribution 4.0 International (CC-BY).

Doi: http://dx.doi.org/10.12944/CRJSSH.2.2.01 


\section{Introduction}

Sexual dysfunctions (SD) are considered situations in which the organic components of the sexual response present some alteration. This functional change may have an organic or psychosocial cause. ${ }^{1}$ Examples are psychosocial factors, social institutions (church and family), taboos, beliefs, sexual violence, among others. Organic factors include genetic or congenital anomalies, acute and chronic diseases, psychoactive drugs, among others. ${ }^{2}$

In women, according to the Diagnostic and Statistical Manual of Mental Disorders (DSM-V), SD are classified in female orgasm disorder, female sexual interest / arousal disorder, and genitopelvic pain / penetration disorder. ${ }^{3}$ Epidemiological data in Brazil indicate that lack of desire (34.6\%) and difficulties in obtaining orgasm $(29.3 \%)$ are the main SD. ${ }^{4}$

Female orgasm disorder is defined as difficulty in reaching orgasm and / or the very low intensity of orgasmic sensations. Female sexual interest / arousal disorder, on the other hand, includes the absence or decrease of sexual interest, absent thoughts or fantasies and lack of responsive desire. Little or no motivation (reasons / incentives) to try to become sexually aroused. The lack of interest must be more significant than that of the natural shortening of the life cycle and / or duration of the relationship. And lastly, genitopelvic pain / penetration disorder is defined as any difficulty with one (or more) of the following symptoms: vaginal penetration during intercourse, intense vulvovaginal or pelvic pain during vaginal intercourse or attempted penetration, intense fear or anxiety of vulvovaginal or pelvic pain in anticipation of, during or as a result of vaginal penetration, tightness or marked contraction of the pelvic floor muscles during attempts at vaginal penetration. All DS mentioned above must be recurrent and persistent for a minimum of 6 months and cause significant distress to the woman. ${ }^{4}$

The already established Permission, Limited Information, Specific Suggestions, Intensive Therapy (PLISSIT) ${ }^{5}$ illustrates the fact that a significant portion of of sexual problems is liable to a less complex approach and does not require intensive sexual therapy. This because many sexual complaints are related to inadequacy not sexual dysfunction. This model, in addition to enable the gynecologist to approach cases of less complexity (anatomical causes, some disorders psychology, ignorance of the anatomy), provides for the from the sex therapist to the most complex cases. This one model has been considered as the one that best meets the etiological diversity of sexual complaints. ${ }^{6,7}$

Sexual education begins at school, and the school must inform and discuss the different taboos, prejudices, beliefs and attitudes. Thus, the goal of sexual orientation work at school is to contribute so that students can develop, expressed and experienced their sexuality with pleasure and responsibility. ${ }^{8}$ The family plays a fundamental role in the sexual being, as well as cultural issues, influencing the way sexual education is transmitted, suggesting how the individual will experience their sexuality. ${ }^{2}$

For cultural reasons, until recently, female sexuality was linked only to reproduction. Women have been conditioned, through culturally transmitted teachings, to repress their sexuality. Thus, even if there are changes in cultural patterns, there is a divergence between actual behavior and the previously accepted cultural norm, which generates conflicts in most women. $^{2}$

Beliefs and sexual education fit into the contributing factors for the onset of SD, and its consequences need to be further understood. Thus, understanding the woman as a whole and recognizing the factors that lead to the development of SD is of paramount importance for an individualized physical therapy approach. Therefore, the aim of this study is to review the influence of beliefs and sexual education on the development of female SD.

\section{Methods \\ Design}

Articles in English, Spanish and Portuguese were selected, without restriction on the date of publication.

\section{Eligibility Criteria}

Publications should discuss the influence of beliefs and sexual education on female SD were included. There was no restriction on the methodological design of the studies, but publications in the form 
of research project, preliminary or conceptual data, news, interviews and articles outside the research subject with evaluation of other variables were excluded.

\section{Information Sources}

The papers included were available in the databases of SciELO, PubMed and Virtual Health Library. The search period ended in March $2^{\text {nd }}-27^{\text {th }}, 2018$. Three search themes were combined using the Boolean operators "AND" and "OR". The search agreeded in the title/abstract the following keywords: "female sexual dysfunctions", "beliefs" e "sexual education".

\section{Selection Phases}

Publications containing the keywords searched in the title or abstract were tracked. Studies with abstracts available and whose whole text could be accessed for free were selected, they were read for data extraction. With the previously defined sample, an exploratory reading was carried out, using a proper form, specifically devised for data analysis and extraction. Items considered were: objectives, methodological design, and place where the study was developed; sample size, assessment and main results.

\section{Data Analysis}

After collection, the data were consolidated in a data base for analysis. Due to the methodological heterogeneity and the different outcomes, a descriptive analysis of results was carried out. The analysis sought to identify the main reflections and discussions about the theme. The data presentation followed strictly the terminology used by the authors.

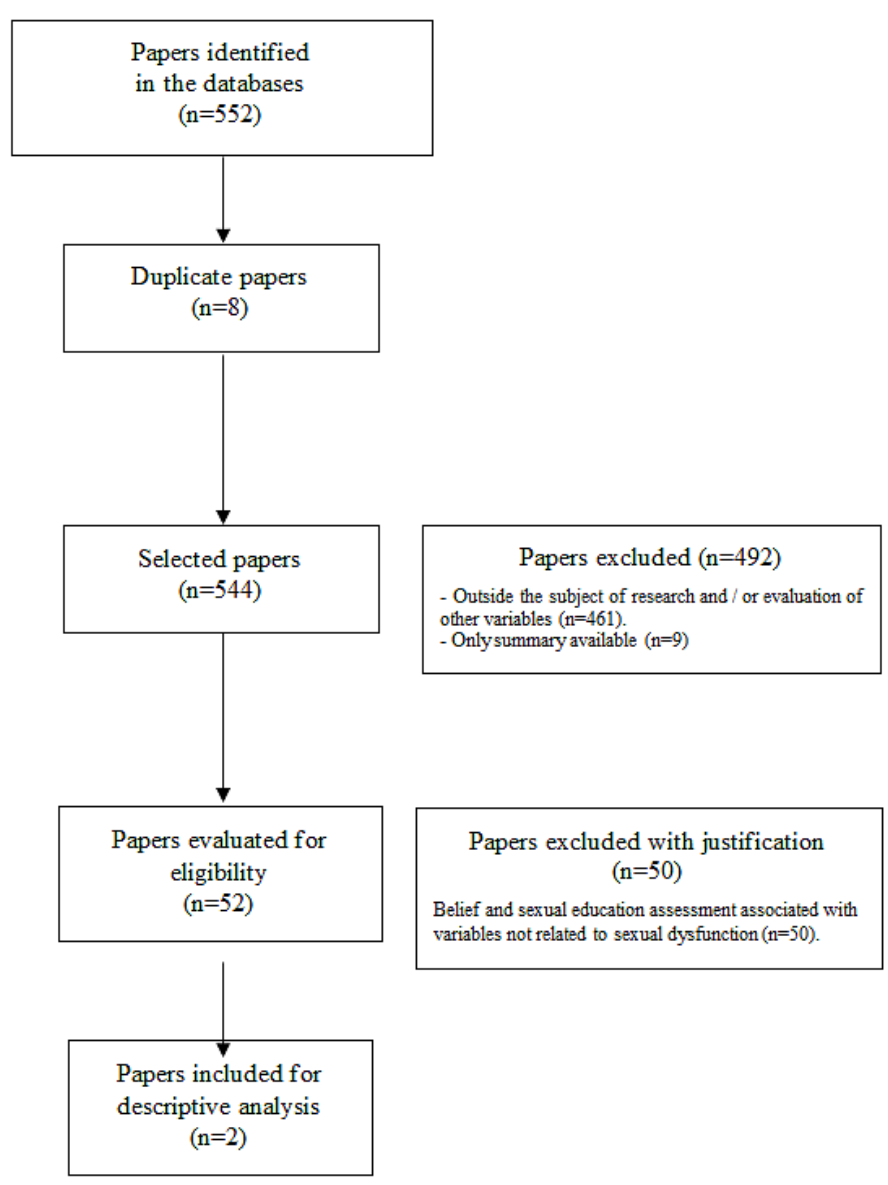

Fig.1: Flowchart with the number of papers identified, excluded and included in the literature review 
Results

Seventy-six publications were found in SciELO, 472 in PubMed and 4 in the Virtual Health Library, totaling 552 articles. Considering the exclusion criteria, only two articles were considered able for review (Figure 1).

Table 1: General features of the studies included regarding objectives

\begin{tabular}{llllll}
\hline Author (year) & Journal & Country & Design & Sample & Mean Age \\
\hline $\begin{array}{l}\text { Nobre et al., } \\
(2008)^{12}\end{array}$ & $\begin{array}{l}\text { Journal of Sex \& } \\
\text { Marital Therapy }\end{array}$ & Portugal & $\begin{array}{l}\text { Randomized } \\
\text { clinical trial }\end{array}$ & 207 women & $\begin{array}{l}28.7 \text { a } 30.4 \\
\text { years. }\end{array}$ \\
$\begin{array}{l}\text { Sabetiet al., } \\
(2018) 1^{4}\end{array}$ & $\begin{array}{l}\text { Nursing Practice } \\
\text { Today }\end{array}$ & Iran & $\begin{array}{l}\text { Randomized } \\
\text { controlled } \\
\text { clinical trial }\end{array}$ & 130 women & 35 years. \\
\hline
\end{tabular}

The general characteristics of the studies are shown in Table 1. The total sample size was 337 women with ages ranging from 28.7 to 35 years. The studies in
Portugal and Iran. The main results of the included articles are listed in Table 2.

Table 2: Characteristics and main results evidenced from the publications selected Author, year

\begin{tabular}{|c|c|c|c|c|}
\hline & Aim & Assessement & Main results & Discussion \\
\hline $\begin{array}{l}\text { Nobre et al., } \\
(2008)^{12}\end{array}$ & $\begin{array}{l}\text { To evaluate } \\
\text { cognitive } \\
\text { and } \\
\text { emotional } \\
\text { variables } \\
\text { associated } \\
\text { with } \\
\text { different } \\
\text { SD in } \\
\text { women. }\end{array}$ & $\begin{array}{l}\text { A clinical evaluation } \\
\text { was performed to } \\
\text { identify SD by a } \\
\text { group of sexual the } \\
\text { rapists. Then, the } \\
\text { following question- } \\
\text { naires were applied: } \\
\text { The Questionnaire } \\
\text { of Cognitive Schema } \\
\text { Activation in Sexual } \\
\text { Context (QCSASC), } \\
\text { The Sexual Dysfun- } \\
\text { ctional Beliefs Ques- } \\
\text { tionnaire (SDBQ), } \\
\text { Sexual Modes } \\
\text { Questionnaire } \\
\text { (SMQ) and Female } \\
\text { Sexual Function } \\
\text { Index (FSFI). }\end{array}$ & $\begin{array}{l}\text { Regarding sexual beliefs, } \\
\text { the hypoactive desire } \\
\text { group scored significantly } \\
\text { for belief in sexual desire } \\
\text { and pleasure as a sin } \\
(p<.01) \text { and in age- } \\
\text { related beliefs ( } p<.05) \text {. } \\
\text { The results indicated } \\
\text { a combination of four } \\
\text { variables as the best } \\
\text { combination: belief in } \\
\text { sexual desire as sin, } \\
\text { sexual conservatism, } \\
\text { lack of erotic thoughts, } \\
\text { and thoughts of failure } \\
\text { and disconnection; The } \\
\text { effect of these predictors } \\
\text { was statistically } \\
\text { significant ( } p<0.001) \text {. }\end{array}$ & $\begin{array}{l}\text { Sexual conservatism, the } \\
\text { belief that sexual desire } \\
\text { and pleasure are sinful } \\
\text { seem to be closely related } \\
\text { to hypoactive sexual desire } \\
\text { and, to some extent, to } \\
\text { the difficulties of arousal } \\
\text { in women. Regarding } \\
\text { orgasmic disorders, the } \\
\text { role of body image beliefs } \\
\text { can be highlighted. The } \\
\text { results indicated a greater } \\
\text { tendency of this clinical } \\
\text { group to present beliefs } \\
\text { to present beliefs about } \\
\text { the central role of body } \\
\text { image in sexual activity. }\end{array}$ \\
\hline $\begin{array}{l}\text { Sabeti et al., } \\
(2018) 1^{4}\end{array}$ & $\begin{array}{l}\text { To describe } \\
\text { the impact } \\
\text { of the sexual } \\
\text { education } \\
\text { program on } \\
\text { improving the } \\
\text { sexual }\end{array}$ & $\begin{array}{l}\text { A specific question } \\
\text {-naire containing } \\
\text { personal and family } \\
\text { information was } \\
\text { applied. To measure } \\
\text { sexual function, Fem } \\
\text {-ale Sexual Function }\end{array}$ & $\begin{array}{l}\text { After three months, } \\
\text { the sexual behaviors } \\
\text { of Intervention Group } \\
\text { were significantly much } \\
\text { better than the Control } \\
\text { Group }(p<0.0001) \text {. In } \\
\text { addition, in the Interven }\end{array}$ & $\begin{array}{l}\text { The sexual healtheducation } \\
\text { is effective in improving } \\
\text { female sexual function, } \\
\text { which may prevent the } \\
\text { onset of possible SD. }\end{array}$ \\
\hline
\end{tabular}




\begin{tabular}{|c|c|c|}
\hline $\begin{array}{l}\text { behavior } \\
\text { of married } \\
\text { women. }\end{array}$ & $\begin{array}{l}\text { Index (FSFI) was } \\
\text { used. Subsequently, } \\
\text { the women were } \\
\text { divided into two } \\
\text { groups: Intervention } \\
\text { and Control. The Inter } \\
\text {-vention Group gained } \\
\text { access to information } \\
\text { on sexual education } \\
\text { and the Control Group } \\
\text { received no guidance. } \\
\text { Three months after the } \\
\text { intervention, both } \\
\text { groups answered the } \\
\text { questionnaires again. }\end{array}$ & $\begin{array}{l}\text {-tion Group the mean } \\
\text { total score of sexual } \\
\text { function after the inter } \\
\text {-vention period was } \\
\text { significantly different } \\
\text { from the previous } \\
\text { one }(p<0.0001) \text {. }\end{array}$ \\
\hline
\end{tabular}

\section{Discussion}

This study aimed to identify if there is influence of beliefs and sexual education in the development of female SD. Through searching the databases, 552 related articles were found. It was observed that a number of articles evaluated sexual education and/or beliefs associating them to other variables different from the proposal of this study. Thus, only two publications were considered fit for this literature review.

In Brazil, the Study of the Brazilian's Sexual Life studied, ${ }^{3} 148$ women in 18 cities. The results showed that $51 \%$ of women reported some SD. Forty-nine percent of women had at least one $\mathrm{SD}$, with hypoactive sexual desire being the most common (26.7\%) followed by dyspareunia (23.1\%) and orgasmic dysfunction (21\%). There was a high prevalence of dysfunction at advanced ages and low educational levels. ${ }^{4,9}$ In other countries, SD rates reach $43 \%$ in total. Desire disorders are the most prevalent (64\%), followed by orgasm disorder (35\%), arousal $(31 \%)$ and pain $(26 \%) .{ }^{10}$

Hypoactive Sexual Desire is characterized by the absence or reduction of the desire for sexual activity and sexual fantasies, persistently and recurrently. ${ }^{11}$ It was observed in the study by Nobre et al., ${ }^{12}$ that conservative sexual beliefs seem to be closely related to hypoactive sexual desire and, to some extent, to arousal difficulties. Regarding sexual beliefs, the Hypoactive Desire Group visualized the belief of sexual desire and pleasure as a sin, presenting statistically significant results $(p<.01)$. Such findings may contribute to the treatment strategies used for hypoactive sexual desire.

In a study conducted with a sample of 1,219 women identified that $49 \%$ of them reported some SD. Twenty-one percent presented orgasmic dysfunction. ${ }^{4}$ This SD is conceptualized as "difficulty in reaching orgasm and / or the very low intensity of orgasmic sensations". ${ }^{3}$ The study by Nobre et al.,12 related body image beliefs to orgasmic disorders. The results indicated a greater tendency of this sample to present beliefs about the central role of body image in sexual activity. Women linked thoughts of low self-image during sexual activity and such thoughts seemed to contribute to the difficulty of acceptance in front of their body image, which was associated with the orgasmic difficulty of these women.

Self-knowledge may be linked to body image and sexual health education. Self-knowledge is fundamental to full sexuality and emphasizes that knowing oneself is observing, touching and respecting biological phenomena. ${ }^{13}$ Therefore, self-knowledge provides the individual with self-awareness, being an important factor for the prevention of SD.

Sabeti et al., ${ }^{14}$ described the impact of the sexual education program on improving the sexual behavior of married women, realizing that sexual health education is effective in improving female sexual 
function, which may prevent the onset of possible SD. Note that it is necessary to include sexual education as a women's health care service. The theme needs to be further debated and seen as a strategy to improve female sexual health.

Sexual education should start when the child enters school, developing throughout the school period. ${ }^{15}$ This education will be important for children and adolescents in the future to have more responsibility for sexual life, less prejudice in social relations, more informed about the body and sexuality and with better choices and preventive attitudes. It is considered that the sooner the individual comes into contact with sexual education, the lower the chances of developing attitudes that may generate possible SD.

The aims of sexual education are to promote healthy sexuality, ie to contribute to a more informed, rewarding, autonomous and responsible experience of sexuality. This involves seeking and clarifying values, structuring attitudes, developing responsible behaviors, accepting diversity, promoting gender equality and refusing violence or coercion. It is not just about sex-related issues, but it also involves exploring key concepts that include human development, affective and emotional characteristics of relationships, personal skills, sexual behavior, sexual health and sexuality. aspects related to society and culture, such as sensitivity and respect for difference. ${ }^{16}$

The quality of sexual education in schools is known to be enhanced by the involvement of parents, teachers, students and the community in this field of education. Comprehensive sexuality education is advocated as one of the most effective perspectives in promoting healthy sexuality. Three key principles can be distinguished: multi-stakeholder involvement, cited above, exploration of a broad set of topics, including a positive view of sexuality (eg, improved communication, increased relational literacy) and not just the reduction of problems arising from sexual behavior [eg, prevention of sexually transmitted infections (STIs), unwanted pregnancies] and the enhancement of life-cycle sexual education, adapted to the level of development and early onset. These principles advocated in sexual education are in line with the guidelines proposed by the World Health Organization for sexual education in Europe. ${ }^{17}$

Beliefs and sexual education are part of the context of sexuality. However, an adequate sample of studies that directly analyze the SD against the mentioned variables was not found, which became an important limitation for the construction of this literature review. However, this study opens doors for more research to be carried out within this theme, considering its importance in women's health.

\section{Conclusion}

Through this review it was observed that there seems to be a relationship between beliefs and hypoactive sexual desire, as well as beliefs about body image and orgasmic disorders. On the other hand, sexual health education proved to be effective in improving female sexual function, which may prevent the onset of SD.

Overall, these findings glimpsed an interrelation between sexual education, beliefs and SD. However, future research needs to identify the correlation between these variables further, with larger sample size and greater methodological rigor.

The scarcity of papers addressing the influence of education and beliefs on female SD demonstrates the importance and need for further research using specific markers to contribute to a broader and more effective discussion.

\section{Funding}

The author(s) received no financial support for the research, authorship, and/or publication of this article.

\section{Conflict of Interest}

The authors do not have any conflict of interest.

\section{References}

1. Moreno AL. (2009). Fisioterapia em Uroginecologia. 2. Ed. Barueri: Manole.
2. Etienne M. (2011). Sexualidade, atividade sexual e disfunções. Ferreira CHJ. (Ed), 
Fisioterapia na saúde da mulher. teoria e prática. Rio de Janeiro: Guanabara Koogan.

3. American Psychiatric Association. (2013). Diagnostic and Statistical Manual of Mental disorders - DSM-5. $5^{\text {th }}$.ed. Washington: American Psychiatric Association.

4. Abdo CHN. Oliveira Jr WM. Moreira Jr ED. Fittipaldi JAS. (2004). Prevalence of sexual dysfunctions and correlated conditions in a sample of Brazilian women-results of the Brazilian study on sexual behavior (BSSB). International Journal of Impotence Research, 16(2), 160.

5. Annon J. (1976) Behavioral treatment of sexual problems. New York: Harper \& Row.

6. Frank JE, Mistretta P, Will J. (2008). Diagnosis and treatment of female sexual dysfunction. American Family Physician, 77(5), 635-42.

7. Taylor B, Davis S. (2006). Using the extended PLISSIT model to address sexual healthcare needs. Nursing Standard, 21(11), 35-40.

8. Ministério da Educação (2010). Orientação sexual. Retrieved from: http://portal.mec.gov. br/seb/arquivos/pdf/livro102.pdf.

9. Abdo CHN. (2004). Estudo da Vida Sexual do Brasileiro (ESVB). São Paulo: Bregantini.

10. Laumann EO. Paik A. Rosen RC. (1999). Sexual dysfunction in the United States: prevalence and predictors. Journal of the American Medical Association, 281(6), 537-44.

11. Pablo C. Soares C. (2004). As disfunções sexuais femininas. Revista Portuguesa de Clínica Geral, 20, 357-370.

12. Nobre PJ (2008). Cognitive and emotional predictors of female sexual dysfunctions: preliminary findings. Journal of Sex \& Marital Therapy, 34:325-342.

13. Meira VP. (2011). Sexualidade Plena. 2.ed. Tatuí: Casa Publicadora Brasileira.

14. Sabeti F. Sadat-Tavafian S. Zarei F. (2018). O efeito da intervenção educativa sobre a função sexual das mulheres referidas centro de saúde do sul de Teerã. Prática de Enfermagem Hoje.

15. Ribeiro M. (1990). Educação Sexual e Metodologia. São Paulo: EPU.

16. Alvarez MJ. Pinto AM. (2012). Sexuality education: attitudes, knowledge, comfort and willingness of portuguese teachers. Aletheia, (38-39), 8-24.

17. WHO (2010). Standards for sexuality education in Europe: A framework for policy makers, educational and health authorities and specialists. Cologne: Federal Centre for Health Education, BzgA. 